\title{
UDC 57.043:615.832.9:615.33-086.83 Freezing Regimens and Gel Carrier Composition Influence Safety of Saccharomyces boulardii Immobilized Yeast Cells
}

Реферат: У роботі досліджували вплив доданих до альгінатного гелю дмСо і сахарози на життєздатність іммобілізованих клітин дріжджів Saccharomyces boulardii після швидкого та повільного охолодження до $-196^{\circ} \mathrm{C}$. За допомогою термомеханічного аналізу показано, що під час охолодження до $-196^{\circ} \mathrm{C}$ розчинів $1 \%$-го альгінату натрію з додаванням $20 \%$ сахарози або 5\% ДМСО отримані криві мали перегини, відповідні кожній складовій розчинів. Фазові перетворення, зумовлені присутністю ДМСО і сахарози в розчинах альгінату натрію, спостерігалися за більш низьких температур, ніж у розчині альгінату натрію без домішок. В експериментах із вивчення впливу режимів охолодження на дріджджові клітини встановлено, що найвищі показники життєздатності як вільних клітин, суспендованих у розчинах альгінату натрію, ДМСО, сахарози, так і клітин, іммобілізованих у гелевих гранулах, забезпечувало охолодження зі швидкістю 1 град/хв до $-40^{\circ} \mathrm{C}$ з подальшим зануренням у рідкий азот. Показники життєздатності іммобілізованих клітин підвищувалися після додавання до альгінатного гелю окремо ДМСО та сахарози, а також їх комбінацій. Максимальна життєздатність іммобілізованих клітин була в гранулах гелю, який містив наступні комбінації кріопротекторів: 5\% ДМСО і 10\% сахарози, 5\% ДМСО і 20\% сахарози, 10\% ДМСО і $10 \%$ сахарози та $10 \%$ ДМСО і $20 \%$ сахарози.

Ключові слова: кріоконсервування, іммобілізація клітин, альгінат, диметилсульфоксид, сахароза, Saccharomyces boulardii.

Abstract: The effect of DMSO and sucrose added to alginate gel on the viability of immobilized Saccharomyces boulardii yeast cells after rapid and slow cooling to $-196^{\circ} \mathrm{C}$ has been studied. Thermomechanical analysis revealed the inflection of phase transitions corresponding to each component of the solutions when cooling those of $1 \%$ sodium alginate contained $20 \%$ sucrose or $5 \%$ DMSO down to $-196^{\circ} \mathrm{C}$. Phase transitions caused by the presence of DMSO and sucrose in sodium alginate solutions were observed at lower temperatures than in additive-free sodium alginate solution. In experiments to study the effect of cooling regimens on yeast cells, it was found that the highest viability of free cells suspended in solutions of sodium alginate, DMSO, sucrose, as well as the cells immobilized in gel granules, was provided by a cooling rate of $1 \mathrm{deg} / \mathrm{min}$ followed by immersion in liquid nitrogen. The viability of immobilized cell increased after adding of either DMSO or sucrose separately, as well as their combinations to the alginate gel. The maximum viability of immobilized cells was found in gel granules, which contained the following combinations of cryoprotectants: $5 \%$ DMSO and $10 \%$ sucrose, $5 \%$ DMSO and $20 \%$ sucrose, $10 \%$ DMSO and $10 \%$ sucrose and $10 \%$ DMSO and $20 \%$ sucrose.

Key words: cryopreservation, cell immobilization, alginate, dimethylsulfoxide, sucrose, Saccharomyces boulardii.

У світовій практиці все більшого поширення набувають системи доставлення ліків, тривимірні культури і тканинно-інженерні конструкції, біокаталізатори, лікувально-профілактичні препарати й продукти харчування на основі іммобілізованих у гелевих носіях клітин про- та еукаріотів і біологічно активних сполук [16, 17, $22,23,27,31]$. У якості гелевих носіїв найчастіше використовують нековалентні та іонотропні гелі 3 полісахаридів природного походження [4]. Ці гелі зазнають біодеградації, вони $\epsilon$ мало- або нетоксичними, не мають антигенних властивостей $[8,30]$. У зв'язку з цим набуло актуальності розроблення технологій довгострокового зберігання іммобілізованих у гелевих носіях клітин

Інститут проблем кріобіології і кріомедицини НАН України, м. Харків

*Автор, якому необхідно надсилати кореспонденцію:

вул. Переяславська, 23, м. Харків, Україна 61016;

тел.: (+38 057) 373-74-35, факс: (+38 057) 373-59-52

електронна пошта: igor.vysek@gmail.com

Надійшла 26.05.2020

Прийнята до друку 19.10.2021
In world practice, drug delivery systems, threedimensional cultures and tissue-engineered constructs, biocatalysts, therapeutic and prophylactic drugs and food products based on pro- and eukaryotic cells immobilized in gel carriers and biologically active compounds are getting more widespread $[6,9,21,22,26,31]$. Non-covalent and ionotropic gels made of polysaccharides of natural origin are most often used as gel carriers [7]. These gels undergo biodegradation, they are lowor non-toxic, and have no antigenic properties $[30,15]$. In this regard, the development of technologies for long-term storage of the cells and biologically active compounds immobilized in gel carriers has become relevant.

Institute for Problems of Cryobiology and Cryomedicine of the National Academy of Sciences of Ukraine, Kharkiv, Ukraine

*To whom correspondence should be addressed:

23, Pereyaslavska str., Kharkiv, Ukraine 61016;

tel..+380 573737435 , fax: +380 573735952

e-mail: igor.vysek@gmail.com

Received 26, May, 2020

Accepted 19, October, 2021

(C) 2021 I.P. Vysekantsev, et al. Published by the Institute for Problems of Cryobiology and Cryomedicine

This is an Open Access article distributed under the terms of the Creative Commons Attribution License (http://creativecommons.org/licenses/by/4.0), which permits unrestricted reuse, distribution, and reproduction in any medium, provided the original work is properly cited. 
i біологічно активних сполук. На сьогодні показано можливість довгострокового зберігання різних іммобілізованих клітин за допомогою кріоконсервування [6, 14, 18, 19, 21, 23-25, 28]. Однак результати більшості досліджень свідчать про те, що кріозахисні властивості гелевих носіїв не здатні забезпечити високу збереженість іммобілізованих клітин. Оскільки гелі $\epsilon$ системою «полімер-розчинник», просторова сітка якої стабілізована міжмолекулярними зв'язками, то імовірно, що введення у цю систему інших кріопротективних речовин і використання певних швидкостей охолодження підвищить життєздатність іммобілізованих клітин після кріоконсервування.

Мета роботи - вивчення впливу заморожування до $-196^{\circ} \mathrm{C}$ із різними швидкостями охолодження на життєздатність клітин пробіотичного штаму дріжджів Saccharomyces boulardii, іммобілізованих в альгінатному гелі без кріопротекторів або в гелі 3 додаванням ДМСО і сахарози.

\section{Матеріали та методи}

Об’єктом дослідження були клітини дріжджів Saccharomyces boulardii CNCM I-745, виділені 3 комерційного препарату «Ентерол» («Biocodex», Франція). Дріжджі вирощували на скошеному сусло-агарі 3 вмістом цукру $8^{\circ}$ за Балінгом [1] при $30^{\circ} \mathrm{C}$ протягом 48 годин. Для отримання суспензії дріжджові клітини змивали 3 поверхні сусло-агару 0,15 М розчином натрію хлориду. В експериментах із використанням термомеханічного аналізу (ТМА) застосовували суспензії клітин у дистильованій воді. Для цього клітини змивали дистильованою водою і додатково тричі відмивали.

До складу альгінатного гелю додавали сахарозу, ДМСО або їх комбінацію. Перед іммобілізацією готували 2\%-ні розчини альгінату натрію, до яких додавали 10, 20, 30\% (v/v) ДМСО або 20, $40 \%$ (w/v) сахарози. Також до розчинів альгінату натрію додавали наступні суміші: 10\% ДМСО i 20 або 40\% сахарози, 20\% ДМСО і 20 або 40\% сахарози, 30\% ДМСО і 20 або 40\% сахарози. Усі розчини стерилізували методом тиндалізації [2]. Для іммобілізації суспензії дріжджових клітин змішували у співвідношенні 1:1 i3 вказаними вище розчинами. Кінцева концентрація ДМСО в альгінатному гелі становила $5,10,15 \%(\mathrm{v} / \mathrm{v})$, сахарози - 10, 20\% (w/v), дріжджових клітин у гелі $-10^{8}$ кл/мл.

Гелеві гранули з іммобілізованими в них клітинами отримували методом іонотропного гелеутворення [26]. Діаметр гранул складав 2 мм.
To date, the possibility of long-term storage of various immobilized cells by cryopreservation has been shown [4, 10, 12, 16, 21-23, 28, 27]. However, the results of most studies suggest that the cryoprotective properties of gel carriers are not able to ensure high safety of immobilized cells. Since gels are polymer-solvent systems, which spatial network is stabilized by intermolecular bonds, it is very likely that the introduction of other cryoprotective substances into this system and the use of certain cooling rates will increase the viability of immobilized cells after cryopreservation.

The research aim was to study the effect of freezing to $-196^{\circ} \mathrm{C}$ at different cooling rates on the viability of cells of the probiotic yeast strain Saccharomyces boulardii immobilized in an alginate gel without cryoprotectants or in a gel with the addition of DMSO and sucrose.

\section{Materials and methods}

The research objects were Saccharomyces boulardii CNCM I-745 yeast cells, isolated from the commercial drug Enterol (Biocodex, France). The yeasts were grown in malt agar slants with a sugar content of $8^{\circ}$ according to Baling [1] at $30^{\circ} \mathrm{C}$ for 48 hours. To obtain a suspension, the yeast cells were washed from the surface of the malt agar with $0.15 \mathrm{M}$ sodium chloride solution. Cell suspensions in distilled water were used in experiments using thermomechanical analysis (TMA). With this aim the cells were washed with distilled water and additionally three more times.

Sucrose, DMSO or a combination thereof was added to the alginate gel. Prior to immobilization, 2\% sodium alginate solutions were prepared, to which $10,20,30 \%(\mathrm{v} / \mathrm{v})$ DMSO or $20,40 \%(\mathrm{w} / \mathrm{v})$ sucrose were added. The following mixtures were also supplemented to the sodium alginate solutions: $10 \%$ DMSO and 20 or $40 \%$ sucrose, $20 \%$ DMSO and 20 or $40 \%$ sucrose, $30 \%$ DMSO and 20 or $40 \%$ sucrose. All solutions were sterilized by tyndalization [3]. To immobilize cells the yeast suspensions were mixed in a ratio of $1: 1$ with the above solutions. The final concentration of DMSO in the alginate gel was $5,10,15 \%(\mathrm{v} / \mathrm{v}), 10,20 \%(\mathrm{w} / \mathrm{v})$ for sucrose, $10^{8}$ cells $/ \mathrm{ml}$ for yeast cells in the gel.

Gel granules with the cells immobilized in them were obtained by ionotropic gelation [25]. The diameter of the granules was $2 \mathrm{~mm}$. The granules were stabilized in $0.2 \mathrm{M} \mathrm{CaCl}_{2}$ solution for $20 \mathrm{~min}$. Hundred granules were placed into $2.0 \mathrm{ml}$ cryotubes (Nunc, USA).

The samples were frozen in two ways: 1 - rapid cooling to $-196^{\circ} \mathrm{C}$ by immersion in liquid nitrogen; 
Стабілізація гранул у $0,2 \mathrm{M}$ розчині $\mathrm{CaCl}_{2}$ тривала 20 хв. У кріопробірки з робочим об'ємом 2,0 мл («Nunc», США) вносили по 100 гранул.

Зразки заморожували двома способами: 1 швидке охолодження до $-196^{\circ} \mathrm{C}$ шляхом занурення у рідкий азот; 2 - повільне охолодження зі швидкістю 1 град/хв до $-40^{\circ} \mathrm{C}$ із наступним зануренням у рідкий азот. Заморожені зразки зберігали у рідкому азоті протягом 10 діб і відігрівали на водяній бані при $37^{\circ} \mathrm{C}$.

Гранули розчиняли в 4\%-му ЕДТА. Життездатність дріжджових клітин оцінювали за колонієутворенням на сусло-агарі [7]. За контроль брали показник життєздатності клітин до заморожування.

Фазові перетворення (ФП) у розчинах альгінату натрію, сахарози і ДМСО вивчали методом TMA [12] із використанням тензодилатометричного комплексу для кріобіологічних досліджень (СКТБ з ДВ ІПКіК НАН України) $[9,10]$. Абсолютна похибка вимірювання температури не перевищувала $2,2^{\circ} \mathrm{C}$. Швидкість охолодження зразків становила 4 град/хв, швидкість нагрівання $-1 \ldots 2$ град/хв. Деформаційне навантаження $\sigma$ на зразок становило 5,3 $\times 10^{5} \mathrm{\kappa} / \mathrm{M}^{2}$.

Статистичну обробку отриманих даних проводили за допомогою програми «Excel» («Microsoft», США) 3 використанням t-критерію Стьюдента. Кількість повторів у кожній серії експериментів $(n)$ дорівнювала 6 . Значущими вважали відмінності при $p<0,05$.

\section{Результати та обговорення}

На першому етапі дослідження за допомогою ТМА визначали граничні значення інтервалів ФП, які відбуваються у водних розчинах альгінату натрію, ДМСО, сахарози та у розчинах 1\%-го альгінату натрію 3 додаванням ДМСО i сахарози. Отримані під час термомеханічного аналізу криві (ТМ-криві) представлено на рис. 1, на якому ТМ-криву дистильованої води (крива 6) подано для порівняння.

Перегин ТМ-кривої 1\%-го водного розчину альгінату натрію в температурному інтервалі $-50 \ldots-37^{\circ} \mathrm{C}$ свідчить про плавлення його аморфної фракції [20] у міжкристалічних прошарках льоду. Фазові перетворення у водних розчинах ДМСО спостерігали за температури нижче $-60^{\circ} \mathrm{C}$, у розчинах сахарози $--50 \ldots-37^{\circ} \mathrm{C}$. У температурному діапазоні вище $-37^{\circ} \mathrm{C}$ відбувалися ФП, пов’язані з присутністю кристалічної фракції води та наявністю солей [3]. ТМ-криві $1 \%$-го розчину альгінату натрію 3 додаванням ДМСО і сахарози мали перегини, відповідні кожній складовій розчинів. Одержані результати свідчать про

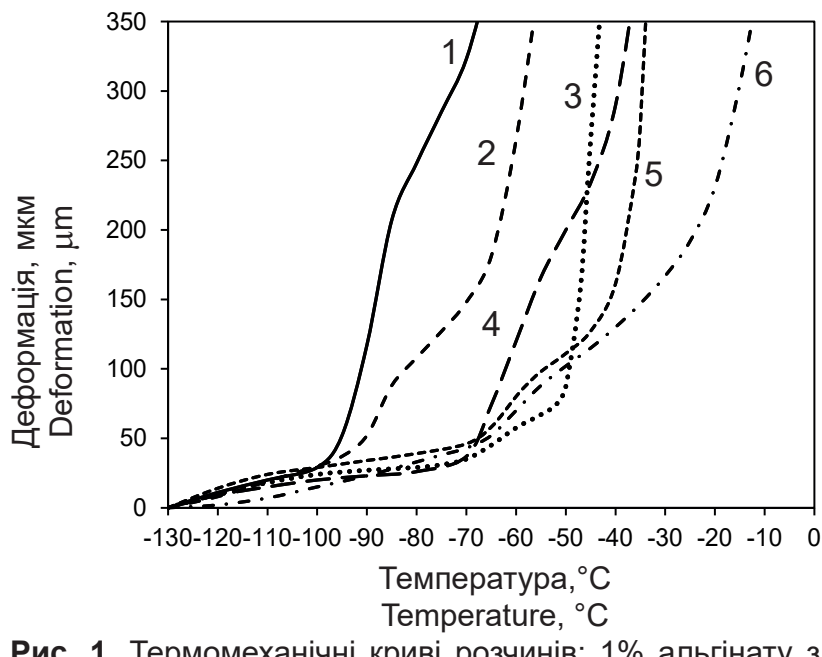

Рис. 1. Термомеханічні криві розчинів: $1 \%$ альгінату 3 додаванням 5\% ДМСО (крива 1), 5\% ДМСО (крива 2), $20 \%$ сахарози (крива 3), $1 \%$ альгінату 3 додаванням $20 \%$ сахарози (крива 4), 1\% альгінату (крива 5) та дистильованої води (крива 6) ( $\left.\sigma=5,3 \times 10^{5} \mathrm{kr} / \mathrm{M}^{2}\right)$.

Fig. 1. Thermomechanical curves of solutions: $1 \%$ alginate with the addition of $5 \%$ DMSO (curve 1), $5 \%$ DMSO (curve 2), 20\% sucrose (curve 3), 1\% alginate with the addition of $20 \%$ sucrose (curve 4 ), $1 \%$ alginate (curve 5 ) and distilled water (curve 6) $\left(\sigma=5.3 \times 10^{5} \mathrm{~kg} / \mathrm{m}^{2}\right)$.

2 - slow cooling at a rate of $1 \mathrm{deg} / \mathrm{min}$ to $-40^{\circ} \mathrm{C}$, followed by immersion into liquid nitrogen. The frozen samples were stored in liquid nitrogen for 10 days and heated in a water bath at $37^{\circ} \mathrm{C}$.

The granules were dissolved in $4 \%$ EDTA. The viability of yeast cells was assessed by colony formation in malt agar [14]. The control was assumed as an index of cell viability prior to freezing.

Phase transformations (PT) in solutions of sodium alginate, sucrose and DMSO were studied by TMA [24] using a tensodilatometric assembly for cryobilogical research (Special Designing and Construction Bureau at the IPC\&C of NAS of Ukraine) $[17,18]$. The absolute error of temperature measurement did not exceed $2.2^{\circ} \mathrm{C}$. The cooling rate of the samples was $4 \mathrm{deg} / \mathrm{min}$, the heating rate made $1 \ldots 2 \mathrm{deg} / \mathrm{min}$. The deforming load $\sigma$ on the specimen was $5.3 \times 10^{5} \mathrm{~kg} / \mathrm{m}^{2}$. The obtained data were statistically processed with Excel software (Microsoft, USA) using Student's t-test. The number of replicates in each series of experiments $(n)$ was 6 . Differences at $p<0.05$ were considered significant.

\section{Results and discussion}

At the first stage of this research we used TMA to determine the limits of PT intervals that occur in aqueous solutions of sodium alginate, DMSO, sucrose and in solutions of $1 \%$ sodium alginate with the addition of DMSO and sucrose. The curves obtained by thermomechanical analysis (TM-curves) 


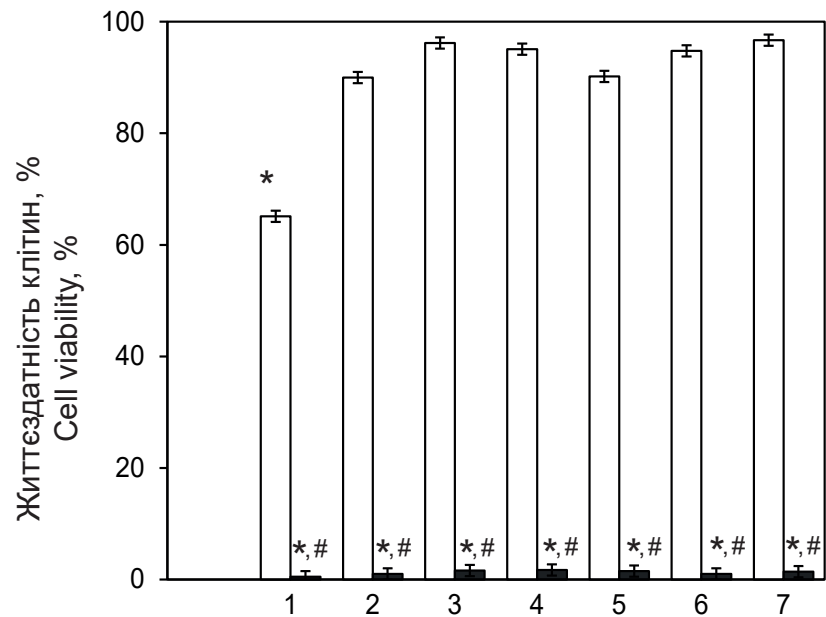

Рис. 2. Показник життєздатності вільних клітин дріжджів S. boulardii, суспендованих у дистильованій воді (1), 1\%-му альгінаті натрію (2) та розчинах кріопротекторів: 5\% ДМСО (3), 10\% ДМСО (4), 15\% ДМСО (5), 10\% сахарози (6), 20\% сахарози (7), після повільного (口) та швидкого (घ) охолодження до $-196^{\circ} \mathrm{C}$. Відмінності значущі $(p<0,05)$ порівняно 3 контролем $\left(^{*}\right)$ та між показниками життєздатності після повільного та швидкого охолодження (\#).

Fig. 2. Viability of free yeast cells of $S$. boulardii suspended in distilled water (1), 1\% sodium alginate (2) and cryoprotectant solutions: $5 \%$ DMSO (3), 10\% DMSO (4), 15\% DMSO 5), $10 \%$ sucrose (6), $20 \%$ sucrose (7), after slow $(\square)$ and fast $(\square)$ cooling to $-196^{\circ} \mathrm{C}$. Differences are significant $(p<0.05)$ compared to control $\left({ }^{*}\right)$ and between viability indices after slow and rapid cooling $(\#)$.

зв'язок основних пошкоджень іммобілізованих у 1\%-му альгінатному гелі клітин із ФП, які присутні за температури понад $-40^{\circ} \mathrm{C}$ і зумовлені кристалічною фазою води та солей. Пошкодження клітин за рахунок ФП альгінату та кріопротекторів (ДМСО, сахароза) суттєво не впливають на життєздатність клітин, оскільки знаходяться нижче $-40^{\circ} \mathrm{C}$. При цьому на ФП при $0 \ldots-40^{\circ} \mathrm{C}$ можуть впливати дані кріопротектори та швидке охолодження.

У наступних експериментах досліджували показники життєздатності вільних клітин $S$. boulardii, суспендованих у дистильованій воді та розчинах альгінату натрію, ДМСО, сахарози, після заморожування до $-196^{\circ} \mathrm{C}$ із різними швидкостями охолодження. Після швидкого охолодження показник життєздатності суспендованих у дистильованій воді клітин становив $0,5 \%$, а у розчинах альгінату натрію, ДМСО, сахарози - від 1,0 до $1,7 \%$. Після повільного охолодження життездатність клітин, суспендованих у дистильованій воді, дорівнювала $65,1 \%$, а у розчинах альгінату натрію, ДМСО, сахарози - залишалася на вихідному рівні (рис. 2).

У третій серії експериментів було досліджено вплив швидкого та повільного охолодження до $-196^{\circ} \mathrm{C}$ на показники життєздатності клітин are presented in Fig. 1, wherein the TM curve of distilled water (curve 6) is shown for comparison.

The inflection of the TM curve of a $1 \%$ aqueous solution of sodium alginate within the temperature range of $-50 \ldots-37^{\circ} \mathrm{C}$ indicates the melting of its amorphous fraction [13] in intercrystalline layers of ice. Phase transitions in aqueous DMSO solutions were observed at temperatures below $-60^{\circ} \mathrm{C}$, in sucrose solutions this was $-50 \ldots-37^{\circ} \mathrm{C}$. Within the temperature range above $-37^{\circ} \mathrm{C}$, there were the PTs associated with the presence of crystalline fraction of water and salts [11]. TM curves of $1 \%$ sodium alginate solution with the addition of DMSO and sucrose had inflections corresponding to each component of the solutions. The findings demonstrate the relation of the main damages of the cells immobilized in $1 \%$ alginate gel with PTs, which are present at temperatures above $-40^{\circ} \mathrm{C}$ and are caused by the crystalline phase of water and salts. Injury to cells due to PT of alginate and cryoprotectants (DMSO, sucrose) does not significantly affect the viability of cells, as they are below $-40^{\circ} \mathrm{C}$. At the same time, these cryoprotectants and rapid cooling can affect the PTs at $0 \ldots-40^{\circ} \mathrm{C}$.

Following experiments explored the viability of free $S$. boulardii cells suspended in distilled water and solutions of sodium alginate, DMSO, sucrose, after freezing to $-196^{\circ} \mathrm{C}$ at different cooling rates. After rapid cooling, the viability of the cells suspended in a distilled water made $0.5 \%$, and in solutions of sodium alginate, DMSO, sucrose these were from 1.0 to $1.7 \%$. After slow cooling, the viability of cells suspended in distilled water was $65.1 \%$, and in solutions of sodium alginate, DMSO, sucrose remained at baseline (Fig. 2).

The third series of experiments investigated the effect of rapid and slow cooling to $-196^{\circ} \mathrm{C}$ on the viability of $S$. boulardii cells immobilized in granules of $1 \%$ alginate gel without additives and gel with the addition of DMSO $(5,10,15 \%)$, sucrose $(10,20 \%)$ both individually and in combinations. The viability of cells immobilized in granules of $1 \%$ alginate gel after rapid cooling was $14.69 \%$, after slow cooling this value made $56.48 \%$ (Fig. 3).

The viability of cells immobilized in alginate gel granules with 10 and $20 \%$ sucrose after rapid cooling was 35.17 and $32.98 \%$, after slow cooling they made 76.08 and $78.2 \%$, respectively.

The viability of cells immobilized in granules of alginate gel containing 5, 10 and 15\% DMSO, after rapid cooling was $12.39 ; 22.43$ and $28.67 \%$, and $69.48 ; 72.54$ and $84.75 \%$ after slow cooling, respectively.

The addition of combinations of DMSO and sucrose to the alginate gel provided a higher pro- 
S. boulardii, іммобілізованих у гранулах 1\%-го альгінатного гелю без домішок та гелю 3 додаванням ДМСО $(5,10,15 \%)$, сахарози $(10,20 \%)$ як окремо, так і в комбінаціях. Життєздатність клітин, іммобілізованих у гранулах $1 \%$-го альгінатного гелю, після швидкого охолодження становила $14,69 \%$, після повільного охолодження $-56,48 \%$ (рис. 3 ).

Показники життєздатності клітин, іммобілізованих у гранулах альгінатного гелю 310 та $20 \%$ сахарози, після швидкого охолодження становили 35,17 і $32,98 \%$, після повільного охолодження - 76,08 і 78,2\% відповідно.

Показники життєздатності клітин, іммобілізованих у гранулах альгінатного гелю 3 вмістом 5, 10 і 15\% ДМСО, після швидкого охолодження дорівнювали 12,$39 ; 22,43$ та $28,67 \%$, а після повільного охолодження - 69,48; 72,54 та 84,75\% відповідно.

Додавання до альгінатного гелю комбінацій ДМСО та сахарози забезпечило більш високий захисний ефект порівняно з гелем, який містив окремо ДМСО або сахарозу. Після швидкого охолодження показник життєздатності клітин, іммобілізованих у гранулах альгінатного гелю 3 додаванням комбінацій 5\% ДМСО з 20\% сахарози, 10\% ДМСО з 10\% сахарози, 10\% ДМСО $320 \%$ сахарози, складали 48,$25 ; 38,31 ; 38,7 \%$ відповідно (рис. 4).

Після повільного охолодження показники життєздатності клітин, іммобілізованих у гранулах альгінатного гелю $з$ додаванням 5 або 10\% ДМСО у комбінації з 10 або 20\% сахарози, не відрізнялися від контрольних.

У всіх зразках гранул гелю 3 додаванням 10 або 20\% сахарози з 15\% ДМСО кількість життєздатних клітин знижувалася. Після швидкого охолодження даний показник у гранулах альгінатного гелю з 10\% сахарози і 15\% ДМСО та в гранулах із $20 \%$ сахарози і $15 \%$ ДМСО становив 26,52 і $26,01 \%$, а після повільного охолодження - 84,82 і 48,84\% відповідно.

Отримані результати свідчать про те, що в процесі кріоконсервування на життєздатність іммобілізованих у гранулах альгінатного гелю S. boulardii значуще впливають три чинника: видова кріорезистентність цих дріжджів, режим охолодження та кріозахисні властивості гелевого носія. S. boulardii є підтипом дріжджів виду Saccharomyces cerevisiae, структурно-функціональна організація яких характерна для нижчих еукаріотів $[5,13]$. Вони, як й інші еукаріотичні клітини, чутливі до дії фізико-хімічних факторів та умов процесу кріоконсервування (див. рис. 2). Показано суттєву різницю в збереженості сус-

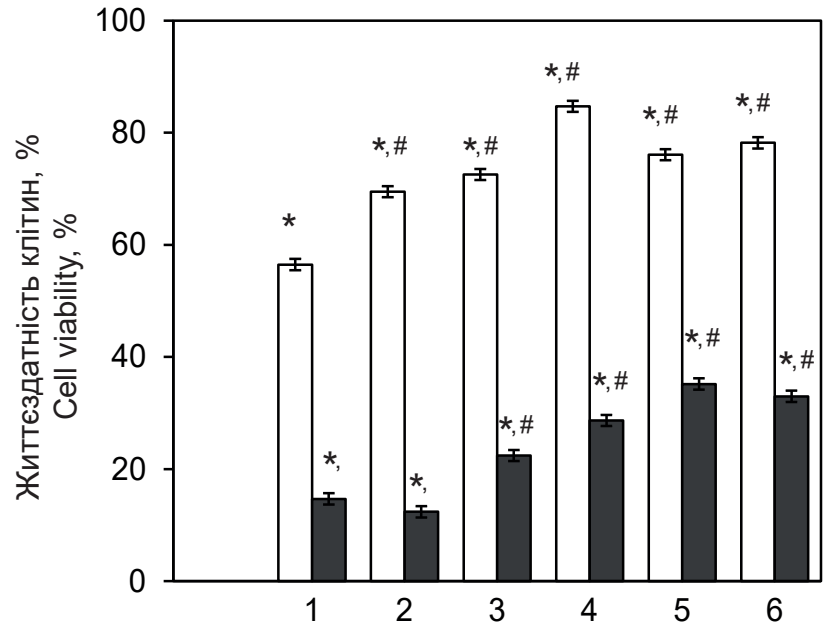

Рис. 3. Показник життєздатності клітин S. boulardii, іммобілізованих у гранулах 1\%-го альгінатного гелю без домішок (1) і з додаванням 5\% ДМСО (2), 10\% ДМСО (3), 15\% ДМСО (4), 10\% сахарози (5), 20\% сахарози (6), після повільного (口) та швидкого (घ) охолодження до $-196^{\circ} \mathrm{C}$. Відмінності значущі $(p<0,05)$ порівняно з контролем $\left(^{*}\right)$ та між показниками життєздатності після повільного та швидкого охолодження (\#).

Fig. 3. Viability of $S$. boulardii cells immobilized in granules of $1 \%$ alginate gel without additives (1) and with the addition of $5 \%$ DMSO (2), $10 \%$ DMSO (3), 15\% DMSO (4), $10 \%$ sucrose (5), $20 \%$ sucrose (6), after slow ( $\square$ ) and fast (घ) cooling to $-196^{\circ} \mathrm{C}$. Differences are significant $(p<0.05)$ compared to control $\left(^{*}\right)$ and between viability indices after slow and rapid cooling $\left({ }^{\#}\right)$.

tective effect compared to the gel containing DMSO or sucrose alone. After rapid cooling, the viability of cells immobilized in alginate gel granules with the addition of combinations of $5 \%$ DMSO with $20 \%$ sucrose, $10 \%$ DMSO with $10 \%$ sucrose, $10 \%$ DMSO with $20 \%$ sucrose, was 48.25 ; $38.31 ; 38.7 \%$, respectively (Fig. 4).

After slow cooling, the viability of cells immobilized in alginate gel granules with the addition of 5 or $10 \%$ DMSO in combination with 10 or $20 \%$ sucrose did not differ from the control.

In all samples of gel granules with the addition of 10 or $20 \%$ sucrose with $15 \%$ DMSO, the number of viable cells decreased. After rapid cooling, this value in granules of alginate gel with $10 \%$ sucrose and 15\% DMSO and in granules with $20 \%$ sucrose and $15 \%$ DMSO was 26.52 and $26.01 \%$, and after slow cooling these were 84.82 and $48.84 \%$, respectively.

Our findings indicate that during cryopreservation the viability of $S$. boulardii immobilized in alginate gel granules is significantly influenced by three factors: species cryoresistance of these yeasts, cooling regimen and cryoprotective properties of the gel carrier. S. boulardii is a subtype of the Saccharomyces cerevisiae yeast, the structure and functions of which is characteristic 

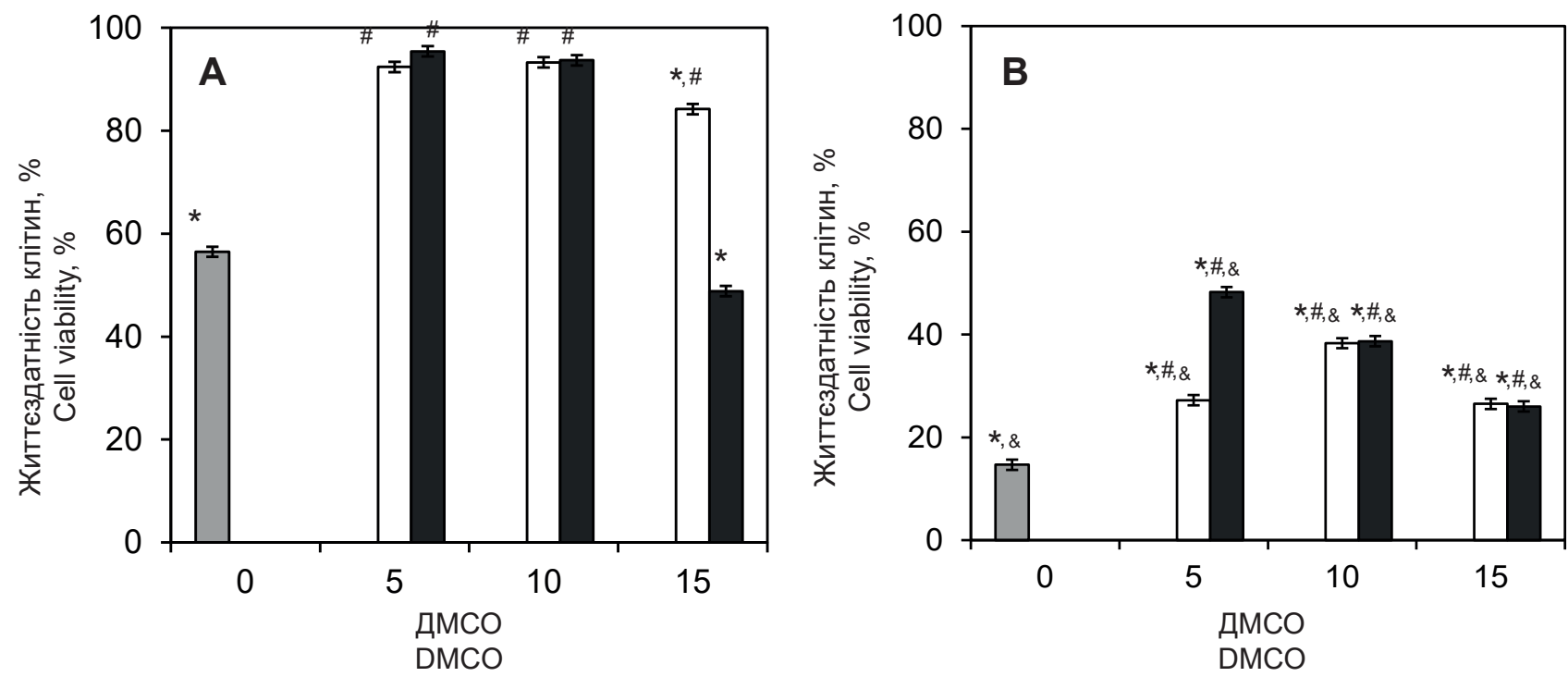

Рис. 4. Показник життєздатності клітин дріжджів S. boulardii, іммобілізованих у гранулах $1 \%$-го альгінатного гелю

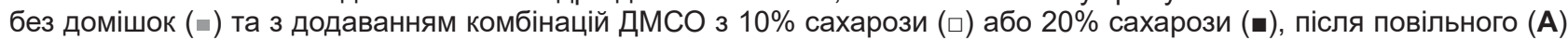
та швидкого (B) охолодження до $-196^{\circ} \mathrm{C}$. Відмінності значущі $(p<0,05)$ порівняно з контролем $\left(^{*}\right)$, показниками життєздатності клітин, іммобілізованих в 1\%-му альгінатному гелі (\#), та між показниками життєздатності після повільного та швидкого охолодження $\left({ }^{\circledR}\right)$.

Fig. 4. Survival of $S$. boulardii yeast cells immobilized in granules of $1 \%$ alginate gel without additives $(\square)$ and with addition of combinations of DMSO with $10 \%$ sucrose (口) or $20 \%$ sucrose (a), after slow (A) and rapid (B) cooling to $-196^{\circ} \mathrm{C}$. Differences are significant $(p<0.05)$ compared to the control $\left.{ }^{*}\right)$, viability of cells immobilized in $1 \%$ alginate gel $(\#)$ and between viability after slow and rapid cooling $\left(^{\circledR}\right)$.

пензій клітин S. boulardii після швидкого та повільного охолодження і виражений кріопротективний ефект ДМСО, сахарози й альгінату натрію. Механізм захисної дії ДМСО та сахарози детально описано в численних публікаціях, але дослідження механізмів кріопротективного впливу розчинів солей альгінових кислот та їхніх іонотропних гелів досі тривають. На сьогодні показано, що гідрогель альгінату натрію проявляє захисні властивості за рахунок тривимірної структури. Ця структура стримує ріст кристалів льоду, утворення водневих зв'язків із молекулами міжклітинної води [29] та формування високов'язкого міжклітинного середовища, що виконує бар'єрну функцію [11].

У проведеному дослідженні показано, що вільні клітини $S$. boulardii, суспендовані у $1 \%$-му розчині альгінату натрію, не гинуть після повільного заморожування. Водночас частина дріжджових клітин, іммобілізованих у гранулах 1\%-го альгінатного гелю, після повільного заморожування гинула. Причини загибелі клітин у гелевих гранулах зі зміцненим поверхневим шаром полімерних ланцюгів альгінату, зв'язаних іонами кальцію [8], потребують більш детального окремого вивчення. Отримані результати демонструють один із можливих шляхів підвищення життєздатності іммобілізованих клітин за рахунок введення в склад альгінатного гелю кріозахисних речовин. of lower eukaryotes [2, 8]. They, like other eukaryotic cells, are sensitive to the action of physicochemical factors and cryopreservation conditions (see Fig. 2). There is a significant difference in the survival of suspensions of $S$. boulardii cells after rapid and slow cooling as well as a pronounced cryoprotective effect of DMSO, sucrose and sodium alginate. The mechanism of protective action of DMSO and sucrose is described in detail in numerous publications, but studies of the mechanisms of cryoprotective effects of solutions of salts of alginic acids and their ionotropic gels are still ongoing. To date, it has been shown that sodium alginate hydrogel exhibits protective properties due to its three-dimensional structure. This structure inhibits the growth of ice crystals, hydrogen bonding between intercellular water molecules [29] and formation of a highly viscous intercellular medium that performs a barrier function [20].

The study showed that free $S$. boulardii cells suspended in $1 \%$ sodium alginate solution did not die after slow freezing. At the same time, some of the yeast cells immobilized in granules of $1 \%$ alginate gel died after slow freezing. The causes of cell death in gel granules with a reinforced surface layer of polymer chains of alginate bound by calcium ions [15] require more detailed separate study. The obtained results demonstrate one of the possible ways to enhance the viability of immobilized cells by introducing cryoprotective substances into alginate gel. 
Після внесення сахарози в гель за рахунок гідратації зменшується кількість вільної позаклітинної води, а у якості осмотичного агента вона зменшує вміст внутрішньоклітинної води. Вочевидь, це приводить до підвищення в'язкості розчинів і зменшення кріопошкоджень клітин під час формування кристалів льоду. Так, у роботі T.A. Calvo та P. Santagapita [15] показано, що під час заморожування розчину альгінату натрію, до якого додавали різні концентрації сахарози, зменшувалася їхня кількість вільної води та активність.

Внесення до складу гелю ДМСО впливає на процеси кристалоутворення в іммобілізованих клітинах, а наявність у ньому комбінацій ДМСО та сахарози забезпечує спільну дію захисних властивостей поза- та внутрішньоклітинного кріопротекторів. Водночас слід зазначити, що після заморожування клітин, іммобілізованих у гранулах гелю, який містить тільки ДМСО, показник їхньої життєздатності збільшувався 3 підвищенням концентрації ДМСО від 5 до 15\%, а показник клітин, іммобілізованих у гелевому носії 3 додаванням сахарози і 15\% ДМСО, знижувався. Це свідчить про зменшення фракції вільної води в гранулах за рахунок гідратації сахарози. В результаті концентрація ДМСО в клітинах і гелі збільшується, що призводить до загибелі частини клітин.

Додавання до альгінатного гелю кріозахисних речовин може зменшувати дію фізико-хімічних чинників, які викликають пошкодження та загибель клітин у гранулах під час заморожування. Це може бути реалізовано за різних низьких температур зберігання.

Отримані результати $є$ перспективними для створення лікувально-профілактичних препаратів і продуктів функціонального харчування на основі іммобілізованих пробіотичних штамів мікроорганізмів і методів їх довгострокового зберігання. Також ці результати можуть бути використані для зберігання іммобілізованих стартових культур мікроорганізмів на біотехнологічних виробництвах.

\section{Висновки}

1. Максимальні показники життєздатності вільних клітин $S$. boulardii, суспендованих у 1\%-му розчині альгінату натрію, розчинах 10, 20\% сахарози, розчинах 5-15\% ДМСО, та клітин, іммобілізованих у гранулах альгінатного гелю, спостерігалися після охолодження зі швидкістю 1 град/хв до $-40^{\circ} \mathrm{C}$ iз наступним зануренням у рідкий азот.
After the incorporation of sucrose into the gel the amount of free extracellular water decreases due to hydration, and as an osmotic agent, it reduces the content of intracellular water. Apparently, this leads to a rise in the viscosity of the solutions and a reduction in the cryoinjury of the cells during the formation of ice crystals. Moreover, T.A. Calvo and P. Santagapita [5] reported that when freezing a solution of sodium alginate, to which various concentrations of sucrose were added, the amount of free water and its activity decreased.

The DMSO incorporation into the gel affects the crystal formation in immobilized cells, and the presence of combinations of DMSO and sucrose in it provides a joint effect of the protective properties of extra- and intracellular cryoprotectants. At the same time, it should be noted that after freezing the cells immobilized in gel granules containing only DMSO, their viability increased with a rise in concentration of DMSO from 5 to $15 \%$, and the rate of cells immobilized in a gel carrier with the addition of sucrose and 15\% DMSO, decreased. This indicates a reduction of the free water fraction in the granules due to hydration of sucrose. As a result, the concentration of DMSO in cells and gels increases, which leads to the death of some cells.

The addition of cryoprotectants to the alginate gel can reduce the effects of physicochemical factors that cause damages and cell death in the granules freezing. This can be implemented at various low storage temperatures.

The obtained results are promising for the development of therapeutic and prophylactic drugs and functional food products based on immobilized probiotic strains of microorganisms and methods of their long-term storage. Also, these results can be used during storage of immobilized starting cultures of microorganisms in biotechnological productions.

\section{Conclusions}

1. Maximum viability of free $S$. boulardii cells suspended in $1 \%$ sodium alginate solution, 10 , $20 \%$ sucrose solutions, 5-15\% DMSO solutions, and cells immobilized in alginate gel granules were observed after cooling at a rate of $1 \mathrm{deg} / \mathrm{min}$ to $-40^{\circ} \mathrm{C}$ followed by immersion into liquid nitrogen.

2. Post-thaw viability of cells immobilized in granules of $1 \%$ alginate gel is significantly lower than in the specimens with the cells suspended in $1 \%$ sodium alginate solution. This is due to the additional mechanisms of cell cryoinjury in the granules. 
2. Після кріоконсервування показник життєздатності клітин, іммобілізованих у гранулах 1\%-го альгінатного гелю, значуще нижчий, ніж у зразках із клітинами, суспендованими в 1\%-му розчині альгінату натрію. Це пов'язано з додатковими механізмами кріопошкоджень клітин у гранулах.

3. Додавання до складу альгінатного гелю ДМСО, сахарози та комбінація цих кріопротекторів підвищують життєздатність іммобілізованих клітин $S$. boulardii після заморожування до $-196^{\circ} \mathrm{C}$. Життєздатність клітин, іммобілізованих у гранулах гелю з додаванням комбінацій ДМСО $(5,10 \%)$ та сахарози $(10,20 \%)$, перевищує даний показник у зразках гелю, до якого додавали тільки одну складову (ДМСО або сахарозу).

\section{Література}

1. Афанасьева ОВ. Микробиологический контроль хлебопекарного производства. Москва: Пищевая промышленность; 1976. $144 \mathrm{c}$.

2. Биргер МО, редактор. Справочник по микробиологическим и вирусологическим методам исследования. Москва: Медицина; 1967. 456 с.

3. Гурина ТМ, Кирилюк АЛ. Определение температурных интервалов фразовых превращений в компонентах криозащитных сред методом термопластической десормации. Проблемы криобиологии. 2012; 22(4): 410-22.

4. Демаков ВА, Максимова ЮГ, Максимов АЮ. Иммобилизация клеток микроорганизмов: биотехнологические аспекты. Биотехнология. 2008(2): 30-45.

5. Дьяков ЮТ, Сергеев ЮВ, редакторы. Новое в систематике и номенклатуре грибов. Москва: Национальная академия микологии. Медицина для всех; 2003. 494 с.

6. Зайков ВС, Петренко ЮА, Труфанова НА, и др. Влияние криоконсервирования путем медленного замораживания или витрификации на жизнеспособность и метаболическую активность мезенхимальных стромальных клеток, заключенных в альгинатные сфреры с диаметром более 1 мм. Проблемы криобиологии и криомедицины. 2014 24(3): 222-30.

7. Луста КА, Фихте БА. Методы определения жизнеспособности микроорганизмов. Пущино: ОНТИ НЦБИ АН СССР 1990. $186 \mathrm{c}$.

8. Манаенков ОВ, Сидоров АИ, Молчанов ВП. Получение полислойных капсул на основе хитозана и солей альгиновой кислоты для инкапсулирования фосфолипидных мицелл. Тонкие химические технологии. 2010; 5(2): 76-81.

9. Осецький ОІ, Гуріна ТМ, винахідники; Інститут проблем кріобіології і кріомедицини НАН України, патентовласник Спосіб визначення фізичного стану розчину кріопротектора в процесі заморожування-відігріву. Патент України № 17624 06.05.1997.

10.Осецький ОІ, Кирилюк ГЛ, Гуріна ТМ, винахідники; Інститут проблем кріобіології і кріомедицини НАН України, патентовласник. Спосіб дослідження розчинів кріопротекторів при заморожуванні. Патент України № 26502. 25.09.2007.

11.Пономарева ВЛ, Кулешова ЛГ, Высеканцев ИП, и др. Кинетика фразовых превращений в процессе охлаждения-отогрева клеток Saccharomyces cerevisiae в альгинатсодержащих криозащитных средах. Проблеми кріобіології і кріомедицини. 2018; 28(3): 212-23.
3. The addition of DMSO, sucrose and a combination of these cryoprotectants to the alginate gel increases the viability of immobilized $S$. boulardii cells after freezing to $-196{ }^{\circ} \mathrm{C}$. The viability of cells immobilized in gel granules with the addition of combinations of DMSO $(5,10 \%)$ and sucrose $(10,20 \%)$ exceeds this value in the gel samples with just one component (DMSO or sucrose) added.

\section{References}

1. Afanas'eva OV. [Microbiological control of bakery production]. Moscow: Pischevaya promyshlennost'; 1976.144 p. Russian.

2. Barnett J. Beginnings of microbiology and biochemistry: the contribution of yeast research. Microbiology-Sgm. 2003; 149: 557-67.

3. Birger MO, editor. [Handbook of microbiological and virological research methods]. Moscow.: Medicine; 1967.456 p. Russian.

4. Cagol N, Bonani W, Maniglio D, et al. Effect of Cryopreservation on cell-laden hydrogels: comparison of different cryoprotectants. Tissue Eng Part C Methods. 2018; 24(1): 20 31.

5. Calvo TA, Santagapita, P. Physicochemical characterization of alginate beads containing sugars and biopolymers. Journal of Quality and Reliability Engineering [Internet]. 2016 Sep 7 [cited Jul 18 2020]; 2016: 9184039. Available from: https://www. hindawi.com/journals/jqre/2016/9184039/.

6. Colom J, Cano-Sarabia M, Otero J, et al. Microencapsulation with alginate/CaCO. Sci Rep. [Internet]. 2017 Jan 25 [cited Jul 18 2020]; 7: 41441. Available from: https://www.nature.com/ articles/srep41441.

7. Demakov VA, Maksimova UG, Maksimov AJ. [Immobilization of microorganism cells: biotechnological aspects]. Biotechnology. 2008 (2): 30-45. Russian.

8. Dyakov UT, Sergeev SE, editors. [New in the systematics and nomenclature of fungi]. Moscow: National Academy of Mycology. Medicine for everyone; 2003.494 p. Russian.

9. Gbassi GK, Vandamme T. Probiotic encapsulation technology: from microencapsulation to release into the gut. Pharmaceutics. 2012; 4(1): 149-63.

10.Gujjari P, Muldrow T, Zhou J. Effect of cryopreservation protocols on the phenotypic stability of yeast. Cryoletters. 2010; 31(3): 261-7.

11. Gurina TM, Kirilyuk AL. Temperature ranges of phase transformations in the cryoprotective media components determined by thermoplastic deformation method. Problems of Cryobiology. 2012; 22(4): 410-22.

12.Gurruchaga H, Saenz Del Burgo L, Hernandez RM, et al. Advances in the slow freezing cryopreservation of microencapsulated cells. J Control Release. 2018; 281: 11938.

13. Huang $\mathrm{H}$, Choi JK, Rao W, et al. Alginate hydrogel microencapsulation inhibits devitrification and enables largevolume low-CPA cell vitrification. Adv Funct Mater. [Internet]. 2015 Nov 25 [cited Jul 18 2020]; 2015; 25(44): 6939-6850. Available from: https://www.ncbi.nlm.nih.gov/pmc/articles/ PMC4667367I.

14.Lusta KA, Fichte BA. [Methods for determining the viability of microorganisms]. Pushchino: ONTI NTsBI AN USSR; 1990.186 p. Russian.

15. Manaenkov OV, Sidorov AI, Molchanov VP. [Preparation of multilayer capsules based on chitosan and alginic acid salts 
12.Тейтельбаум БЯ. Термомеханический анализ полимеров. Москва: Наука; 1979. 236 с.

13.Barnett J. Beginnings of microbiology and biochemistry: the contribution of yeast research. Microbiology-Sgm. 2003; 149 557-67.

14.Cagol N, Bonani W, Maniglio D, et al. Effect of cryopreservation on cell-laden hydrogels: comparison of different cryoprotectants. Tissue Eng Part C Methods. 2018; 24(1): 20-31.

15. Calvo TA, Santagapita P. Physicochemical characterization of alginate beads containing sugars and biopolymers. Journa of Quality and Reliability Engineering [Internet]. 2016 Sep 7 [cited Jul 18 2020]; 2016: 9184039. Available from: https://www. hindawi.com/journals/jqre/2016/9184039/.

16.Colom J, Cano-Sarabia M, Otero J, et al. Microencapsulation with alginate/CaCO. Sci Rep. [Internet]. 2017 Jan 25 [cited Jul 18 2020]; 7: 41441. Available from: https://www.nature.com/ articles/srep41441.

17.Gbassi GK, Vandamme T. Probiotic encapsulation technology: from microencapsulation to release into the gut. Pharmaceutics. 2012; 4(1): 149-63.

18.Gujjari P, Muldrow T, Zhou J. Effect of cryopreservation protocols on the phenotypic stability of yeast. Cryoletters. 2010 31(3): 261-7.

19.Gurruchaga H, Saenz Del Burgo L, Hernandez RM, et al. Advances in the slow freezing cryopreservation of microencapsulated cells. J Control Release. 2018; 281: 119-38.

20.Huang $\mathrm{H}$, Choi JK, Rao W, et al. Alginate hydroge microencapsulation inhibits devitrification and enables largevolume low-CPA cell vitrification. Adv Funct Mater. [Internet] 2015 Nov 25 [cited Jul 18 2020]; 2015; 25(44): 6939-6850. Available from: https://www.ncbi.nlm.nih.gov/pmc/articles/ PMC4667367/.

21. Murua A, Orive G, Hernandez R, Pedraz J. Cryopreservation based on freezing protocols for the long-term storage of microencapsulated myoblasts. Biomaterials. 2009; 30(20): 3495-501.

22.Peek LJ, Middaugh CR, Berkland C. Nanotechnology in vaccine delivery. Adv Drug Deliv Rev. 2008; 60(8): 915-28.

23. Rodriguez S, Tuli R, Wheeler A, et al. Current perspective and advancements of alginate-based transplantation technologies. In: Pereira L, editor: Alginates - recent uses of this natura polymer. IntechOpen [Internet]. 2019 Jun 22 [cited Jul 18 2020]; Chapter 3. Available from: https://www.intechopen.com/ chapters $/ 67763$.

24.Solanki HK, Pawar DD, Shah DA, et al. Development of microencapsulation delivery system for long-term preservation of probiotics as biotherapeutics agent. Biomed Res Int. [Internet] 2013 Aug 21 [cited Jul 18 2020]; 2013 620719. Available from: https://www.hindawi.com/journals/ bmri/2013/620719/.

25. Tedeschi R, De Paoli P. Collection and preservation of frozen microorganisms. Methods Mol Biol. 2011; 675: 313-26.

26.Tsen JH, Huang HY, Lin YP, King VA. Freezing resistance improvement of Lactobacillus reuteri by using cell immobilization. J Microbiol Methods. 2007; 70(3): 561-4

27. Yeung TW, Üçok EF, Tiani KA, et al. Microencapsulation in alginate and chitosan microgels to enhance viability of bifidobacterium longum for oral delivery. Front Microbiol. [Internet] 2016 Apr 19 [cited Jul 18 2020]; 7: 494. Available from: https://www.frontiersin.org/articles/10.3389/fmicb.2016.00494/ full.

28.Zhang C, Zhou Y, Zhang L, et al. Hydrogel cryopreservation system: an effective method for cell storage. Int J Mol Sci. [Internet] 2018 Oct 25 [cited Jul 18 2020]; 19(11): 3330. Available from: https://www.mdpi.com/1422-0067/19/11/ 3330 .

29.Zhang W, Ren X, He J, et al. Application of natural mixed bacteria immobilized carriers to different kinds of organic wastewater treatment and microbial community comparison. J Hazard Mater. 2019; 377: 113-23. for encapsulating phospholipid micelles]. Fine Chemical Technologies. 2010; 5(2): 76-81. Russian.

16.Murua A, Orive G, Hernandez R, Pedraz J. Cryopreservation based on freezing protocols for the long-term storage of microencapsulated myoblasts. Biomaterials. 2009; 30(20): 3495-501.

17. Osetskyi OI, Hurina TM, inventors; Institute for Problems of Cryobiology and Cryomedicine of the NAS of Ukraine, assignee. [Method for determination of physical condition of solution of cryo-protector in process of freezing heating]. Patent of Ukraine №17624. 1997 MAY 06. Ukraine.

18. Osetskyi OI, Kyryliuk HL, Hurina TM, inventors; Institute for Problems of Cryobiology and Cryomedicine of the NAS of Ukraine, assignee. [Method for analyzing cryoprotector solution in freezing]. Patent of Ukraine №26502. 2007 SEP 25. Ukraine.

19.Peek LJ, Middaugh CR, Berkland C. Nanotechnology in vaccine delivery. Adv Drug Deliv Rev. 2008; 60(8): 91528.

20.Ponomareva VL, Kuleshova LG, Vysekantsev IP, et al. Kinetics of phase transformations during cooling-warming of Saccharomyces cerevisiae cells in alginate-containing cryoprotective media. Probl Cryobiol Cryomed. 2018; 28(3): 212-23.

21.Rodriguez S, Tuli R, Wheeler A, et al. Current perspective and advancements of alginate-based transplantation technologies. In: Pereira L, editor: Alginates - recent uses of this natural polymer. IntechOpen [Internet]. 2019 Jun 22 [cited Jul 18 2020]; Chapter 3. Available from: https://www.intechopen. com/chapters/67763.

22.Solanki HK, Pawar DD, Shah DA, et al. Development of microencapsulation delivery system for long-term preservation of probiotics as biotherapeutics agent. Biomed Res Int. [Internet] 2013 Aug 21 [cited Jul 18 2020]; 2013: 620719.Available from: https://www.hindawi.com/journals/ bmri/2013/620719/.

23. Tedeschi R, De Paoli P. Collection and preservation of frozen microorganisms. Methods Mol Biol. 2011; 675: 31326.

24. Teitelbaum BY. [Thermomechanical analysis of polymers]. Moscow: Nauka; 1979. 236 p. Russian.

25.Tsen JH, Huang HY, Lin YP, King VA. Freezing resistance improvement of Lactobacillus reuteri by using cell immobilization. J Microbiol Methods. 2007; 70(3): 561-4.

26.Yeung TW, Üçok EF, Tiani KA, et al. Microencapsulation in alginate and chitosan microgels to enhance viability of bifidobacterium longum for oral delivery. Front Microbiol. [Internet] 2016 Apr 19 [cited Jul 18 2020]; 7: 494. Available from: https://www.frontiersin.org/articles/10.3389/ fmicb.2016.00494/full.

27.Zaikov VS, Petrenko YA, Trufanova NA, et al. Effect of cryopreservation using slow freezing or vitrification on viability and metabolic activity of mesenchymal stromal cells encapsulated within alginate spheres with diameter of 1 $\mathrm{mm}$ and more. Probl Cryobiol Cryomed. 2014; 24(3): 22230 .

28.Zhang C, Zhou Y, Zhang L, et al. Hydrogel cryopreservation system: an effective method for cell storage. Int J Mol Sci. [Internet] 2018 Oct 25 [cited Jul 18 2020]; 19(11): 3330. Available from: https://www.mdpi.com/1422-0067/19/ $11 / 3330$.

29.Zhang W, Ren X, He J, et al. Application of natural mixed bacteria immobilized carriers to different kinds of organic wastewater treatment and microbial community comparison. J Hazard Mater. 2019; 377: 113-23.

30.Zimmermann H, Ehrhart F, Zimmermann D, et al. Hydrogelbased encapsulation of biological, functional tissue: fundamentals, technologies and applications. Appl Phys A. 2007; 89(4): 909-22. 
30.Zimmermann H, Ehrhart F, Zimmermann D, et al. Hydrogelbased encapsulation of biological, functional tissue: fundamentals, technologies and applications. Appl Phys A. 2007; 89(4): 909-22.

31.Żur J, Wojcieszyńska D, Guzik U. Metabolic responses of bacterial cells to immobilization. Molecules [Internet]. $2016 \mathrm{Jul}$ 22 [cited Jul 18 2020]; 21(7): 958. Available from: https://www. mdpi.com/1420-3049/21/7/958.
31.Żur J, Wojcieszyńska D, Guzik U. Metabolic responses of bacterial cells to immobilization. Molecules [Internet]. $2016 \mathrm{Jul}$ 22 [cited Jul 18 2020]; 21(7): 958. Available from: https://www. mdpi.com/1420-3049/21/7/958. 